Jurnal Sistem Informasi dan Sistem Komputer,Vol.6, No.1, Januari 2021

ISSN: 2715-906X (Online)

$10.51717 /$ simkom.v6i1.52

\title{
IMPLEMENTASI APLIKASI MEETING ONLINE PADA VIRTUAL PRIVATE SERVER DI MASA PANDEMI
}

\author{
Abdul Djalil Djayali ${ }^{1}$, Muhammad Muzammil ${ }^{2}$, Abjan Samad ${ }^{3}$ \\ ${ }^{1}$ add@aikomternate.ac.id, ${ }^{2}$ kaptenmozac@gmail.com, ${ }^{3}$ abjansamad@aikomternate.ac.id \\ ${ }^{1,3}$ Akademi Ilmu Komputer, ${ }^{2}$ LPSE Kota Ternate
}

\begin{abstract}
Abstrak
Meningkatnya kebutuhan untuk proses pembelajaran ditengah wabah pandemi COVID19, sangat dirasakan khususnya di Provinsi Maluku Utara, menjadikan Akademi Ilmu Komputer (AIKOM) Ternate perlu mencari alternatif terbaik sehingga proses pembelajaran dimasa pandemi bisa berjalan dengan optimal. Video Meeting seperti Zoom Meeting dan Google Meet menjadi alternatif yang sebelumnya telah diterapkan, akan tetapi dengan mengingatnya kebutuhan akan penerapan ilmu pengetahuan, dan pengabdian, maka dibutuhkan sebuah sistem yang dibangun secara mandiri yang mampu mengatasi kebutuhan-kebutuhan ini. Kebutuhan yang menjadi acuan utama disini adalah berkaitan dengan proses belajar ditengah COVID19, penerapan ilmu, penelitian dan pengabdian kepada masyarakat. Akademi Ilmu Komputer (AIKOM) sebelumnya telah memiliki Virtual Private Server (VPS) yang nantinya akan diimplementasikan juga untuk kebutuhan video meeting selain sebagai media informasi akademik. Menerapkan Video Meeting pada VPS diharapkan mampu menampung jumlah mahasiswa perkelasnya secara online secara bersamaan dan juga mampu untuk me-manage room dan akun. Video meeting yang dibangun mampu berjalan dengan baik sebagaimana yang diharapkan, dengan penggunaan RAM kurang dari yang ada
\end{abstract}

Kata kunci: VPS, Video meeting, Pandemi, COVID19, BigBlueButton

\begin{abstract}
The increasing need for the learning process in the midst of the COVID19 pandemic outbreak, especially in North Maluku province, has made the Ternate Academy of Computer Science (AIKOM) need to find the best alternative so that the learning process during the pandemic can run optimally. Video Meetings such as Zoom Meeting and Google Meet are alternatives that have previously been implemented, but keeping in mind the need for the application of knowledge and dedication, a system that is built independently is needed to be able to address these needs. The need that is the main reference here is related to the learning process in the midst of COVID19, the application of knowledge, research, and community service. The Academy of Computer Science (AIKOM) previously had a Virtual Private Server (VPS) which would later be implemented for video meeting needs other than as a medium for academic information. Implementing a Video Meeting on a VPS is expected to be able to accommodate the number of students per class online simultaneously and also to be able to manage rooms and accounts. Video meetings that are awake are able to run well as expected, with less than existing RAM usage.
\end{abstract}

Keywords: VPS, Video meeting, Pandemic, COVID19, BigBlueButton

\section{Pendahuluan}

Pentingnya pendidikan di Indonesia khususnya di Maluku Utara, semakin pesatnya kebutuhan teknologi di era industri 4.0 memaksa segala sektor untuk mampu memanfaatkan teknologi informasi sebagai penunjang untuk membantu proses bisnisnya. Sama halnya dengan sektor pendidikan. Mahasiswa dan dosen memanfaatkan banyak media pendukung perkuliahan seperti sistem akademik, program merdeka belajar, dan banyak sistem lainnya yang berkaitan dengan teknologi informasi. 
Jurnal Sistem Informasi dan Sistem Komputer,Vol.6, No.1, Januari 2021

ISSN: 2715-906X (Online)

doi) $10.51717 /$ simkom.v6i1.52

Dengan kecanggihan teknologi yang ada saat ini, jarak sudah bukan merupakan masalah. Orang dapat tetap melakukan komunikasi secara langsung, tatap muka, walaupun jaraknya sangat jauh. Salah satu yang dikembangkan untuk memenuhi kepentingan ini adalah dengan video conference. Video conference merupakan salah satu layanan multimedia yang dapat memenuhi keinginan user yang membutuhkan komunikasi langsung secara tatap muka dan interaktif [1].

Di masa pandemi COVID19 yang dinyatakan sebagai global pandemic sejak 2019 oleh World Health Organization (WHO), bulan maret 2020 Maluku Utara mulai merasakan imbasnya, hal ini menuntut Perguruan Tinggi yang ada untuk dapat mencari alternatif belajar yang efisien demi berjalannya roda bisnis. WHO memberikan solusi untuk tetap dirumah (Stay at Home) sebagai upaya untuk mencegah dan memutus penyebaran virus ini. Indonesia melalui Surat Edaran nomor 5 Tahun 2020 Tentang Penyesuaian Sistem Kinerja Pegawai Dalam Upaya Pencegahan Penyebaran Corona Virus Disease 2019 (COVID19) mewajibkan semua sektor pendidikan untuk saat ini meliburkan sementara. Sebagai gantinya untuk para mahasiswa diberikan tugas untuk tetap belajar dirumah, dan tenaga kependidikan untuk bekerja dirumah (Work from Home) [2].

Melalui surat edaran tersebut, timbul masalah pada Akademi Ilmu Komputer (AIKOM) Ternate yang hampir semua aktifitasnya terpaksa harus dilakukan secara online. Ketidaksiapan infrastuktur yang dimiliki dan aktifitas yang biasanya dilakukan secara onsite didalam kelas harus dialihkan untuk dilakukan dari rumah. Pertemuan untuk membahas hal-hal penting akademik pun harus dilakukan secara daring. Hal ini menimbulkan keterkendalaan komunikasi karena infrastruktur yang dimiliki masih belum mewadai hal ini.

Beberapa aplikasi sempat digunakan untuk media pertemuan daring, seperti Google Meet, Zoom Meeting, Facebook Worksplace dan Whatsapp Call Group. Data yang disajikan oleh Statista pada Gambar 1 menunjukkan adanya peningkatan penggunaan aplikasi video meeting di tahun 2020 [3].

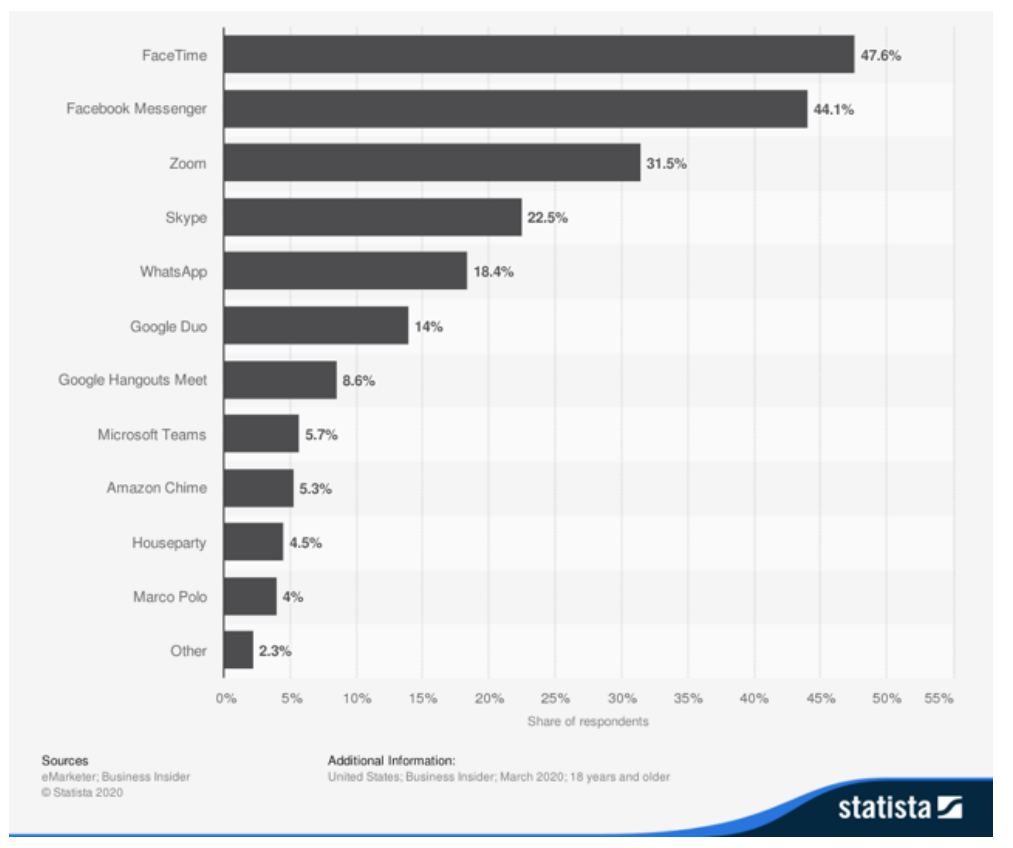

Gambar 1. Peningkatan penggunaan aplikasi video conference di tahun 2020 
Jurnal Sistem Informasi dan Sistem Komputer,Vol.6, No.1, Januari 2021

ISSN: 2715-906X (Online)

\section{$10.51717 /$ simkom.v6i1.52}

Satu dekade lalu, tidak banyak pilihan dalam teknologi video conference, termasuk diantaranya video conference yang diterapkan secara on-premise menggunakan perangkat yang cukup mahal dan implementasi yang kompleks sehingga tidak banyak perusahaan yang menerapkan teknologi ini. Namun saat ini solusi off-premise atau berbasis cloud menjadi trend. Selain itu, kemajuan dalam kekuatan pemrosesan, penyimpanan data, dan API, bersama dengan keberadaan aplikasi seluler dimana melahirkan era baru mobilitas pada perusahaan. Termasuk kemajuan dalam teknologi WebRTC, peningkatan kompatibilitas pada perangkat seluler, dan kecepatan broadband [4].

Akan tetapi setiap aplikasi memiliki kelebihan dan kekurangannya masing-masing. Melihat kebutuhan ini AIKOM Ternate tergerak untuk membangun sebuah sistem video meeting off-premise dengan memanfaatkan Virtual Private Server (VPS) dan aplikasi Opensource yaitu BigBlueButton. BigBlueButton menjadi pilihan dikarenakan video conference seperti Zoom Meeting yang sebelumnya aktif digunakan perlu untuk ditinjau kembali kegunaannya, mengingat Surat Edaran Sekretaris Jenderal Kementerian Pertahanan Nomor SE/57/IV/2020 Tahun 2020 Tentang Aplikasi Teleconference Zoom Tidak Diperkenankan/Digunakan Di Lingkungan Kementerian Pertahanan Terkait Pengamanan Informasi Data, termasuk juga dengan Surat Edaran Kepala BNPT Nomor 8 Tahun 2020 tentang Larangan Penggunaan Aplikasi Video Conference Zoom di Lingkungan BNPT Terkait Pengamanan Data Informasi Data.

Akan tetapi aplikasi Zoom Meeting tidak dilarang penuh untuk digunakan, seperti yang dijelaskan oleh Badan Siber dan Sandi Negara (BSSN) dalam Artikelnya yang berjudul "Telaah Staf Terkait Pemanfaatan Aplikasi Zoom Sebagai Media Online Meeting Yang Banyak Digunakan Saat Ini" [5].

Untuk itu, dalam hal mitigasi kemungkinan-kemungkinan yang tidak diinginkan oleh AIKOM Ternate, maka penulis mengimplementasikan alternatif lain sesuai dengan resource yang dimiliki selain aplikasi video conference yang telah disebutkan diatas. Aplikasi BigBlueButton merupakan aplikasi alternatif yang tepat untuk diterapkan.

Sebelumnya telah ada penelitian yang menggunakan BigBlueButton, hanya saja penerapannya masih menggunakan versi yang lama dan objek penerapannya berbeda dengan yang dilakukan dalam penelitian ini. Penelitian ini menerapkan BigBlueButton dengan versi 2.2.30 dimana pada versi ini telah mengimplementasikan HTML5 yang dapat secara real-time sharing audio, video, slides dan screen sharing serta memiliki kemampuan untuk membagikan video seperti dari Youtube untuk ditonton secara bersama-sama. Selain itu, BigBlueButton juga memiliki kemampuan untuk public/private chat, emojis, shared notes, multi-user whiteboard, polling, dan breakout rooms. BigBlueButton mampu memenuhi kebutuhan dari proses bisnis yang ada di AIKOM Ternate serta mampu untuk menjalankannya hanya dengan menggunakan browser familiar seperti Google Chrome, Safari, Mozilla Firefox dan browser lainnya yang mendukung HTML5 dengan baik pada Desktop maupun Mobile tanpa harus menginstal aplikasi tambahan seperti aplikasi sejenisnya.

Selain itu, BigBlueButton dapat dengan mudah diterapkan pada VPS yang dimiliki oleh AIKOM Ternate sehingga keamanan, resource internet dan hardware yang dimiliki dapat terjaga dan dimaksimalkan dengan lebih baik dari sebelumnya. 
Jurnal Sistem Informasi dan Sistem Komputer,Vol.6, No.1, Januari 2021

ISSN: 2715-906X (Online)

$10.51717 /$ simkom.v6i1.52

2. Landasan Teori

1.1.s (Virtual Private Server)

VPS (Virtual Private Server) adalah teknologi virtualisasi server. Sebuah physical server dibagi menjadi beberapa virtual private sever sehingga setiap VPS terlihat dan bekerja seperti sebuah server mandiri yang sebenarnya. Setiap VPS memiliki Full Root Access, Sistem Operasi, dan pengaturan sendiri untuk init script, users, pemrosesan, filesystem, dan sebagainya termasuk resources server seperti CPU dan RAM yang berdiri sendiri. Berbeda dengan shared hosting yang menggunakan resource server bersama-sama dan saling mempengaruhi proses yang berjalan. Suatu VPS tidak akan mempengaruhi VPS yang lain didalam satu server yang sama [6].

Dalam pemanfaatan VPS kebutuhan untuk perangkat keras (hardware) dan perangkat lunak (software) tergantung dari berapa jumlah VPS yang akan di Host dan juga spesifikasi dari VPS yang diinginkan. Semakin banyak jumlah VPS yang akan diciptakan dan tingginya spesifikasi VPS yang diinginkan maka semakin tinggi pula kebutuhan hardware. Masalah jaringan juga harus diperhatikan karena sebuah VPS harus mempunyai jaringan yang baik khususnya koneksi ke internet [6].

\subsection{Video Conference}

Konferensi video adalah seperangkat teknologi telekomunikasi interaktif yang memungkinkankan dua pihak atau lebih dilokasi berbeda dapat berinteraksi melalui pengiriman dua arah audio dan video secara bersamaan [5].

\subsection{BigBlueButton}

BigBlueButton merupakan aplikasi berbasi web yang bersifat opensource (sumber terbuka) yang berfungsi sebagai sistem konferensi yang dapat digunakan sebagai media pembelajaran atau meeting secara online. Proyek BigBlueButton mempunyai tujuan untuk memberikan pengalaman pembelajaran jarak jauh bagi penggunanya [5,7].

\section{Metode}

Metode yang diterapkan pada penelitian ini adalah secara observatif-kuantitatif dan implementatif-kualitatif. Penjelasan dari metode ini dapat dijelaskan sebagai berikut:

1. Metode Observatif-Kuantitatif merupakan metode yang dilakukan oleh penulis dalam mencari informasi yang berkaitan sebanyak mungkin, mengumpulkannya dalam satu bagan informasi dan kemudian membagi informasi tersebut sesuai dengan yang dibutuhkan. Pengumpulan data paling awal adalah informasi yang berkaitan dengan kebutuhan sistem untuk penerapan aplikasi BigBlueButton ini, dimana informasi ini diperoleh melalui dokumentasi resmi BigBlueButton serta komunikasi dengan beberapa praktisi informasi dan teknologi yang ada di Indonesia [7].

2. Metode Implementatif-Kualitatif merupakan metode yang diterapkan penulis pada sistem yang dimiliki secara langsung dan mengujinya dengan melihat beban yang dihasilkan pada server. Termasuk kualitas yang dirasakan oleh para pengguna sistem, mulai dari pembuatan akun, pembuatan room, menjalankan, mengatur akses dan memanfaatkan fitur yang dimiliki oleh BigBlueButton kepada pengguna. 
Jurnal Sistem Informasi dan Sistem Komputer,Vol.6, No.1, Januari 2021

ISSN: 2715-906X (Online)

$10.51717 /$ simkom.v6i1.52

4. Hasil dan Pembahasan

Dalam penerapannya, penulis menggunakan spesifikasi VPS seperti pada tabel 1 berikut:

Tabel 1. Spesifikasi Virtual Private Server

\begin{tabular}{ll}
\hline Spesifikasi Hardware & Keterangan \\
\hline$C P U$ & 2 Core \\
$R A M$ & $8 \mathrm{~GB}$ \\
Storage & $500 \mathrm{~GB}$ \\
\hline
\end{tabular}

Sedangkan untuk kebutuhan software, penulis menggunakan spesifikasi seperti pada tabel 2 berikut ini:

Tabel 2. Spesifikasi Software

\begin{tabular}{ll}
\hline Spesifikasi Software & Keterangan \\
\hline Sistem Operasi & Ubuntu Server 16.04.4 LTS \\
Network & - TCP $80 \& 443$ \\
& - UDP $16384-32768$ \\
& - ipv4 address \\
Bandwidth & looMBps \\
Subdomain & bbb.aikom.ac.id \\
\hline
\end{tabular}

Pada proses instalasi penulis menyiapkan kebutuhan dari aplikasi BigBlueButton yang fokus pada instalasi sistem operasi dan aplikasi pendukung serta pendukung lainya diluar server seperti penyiapan domain dan jaringan, serta mendapatkan sertifikat $S S L$, sedangkan pada proses instalasinya lebih fokus kepada teknik instalasi BigBlueButton itu sendiri. Berikut tahapan untuk proses instalasinya:

1. Instalasi Ubuntu 16.04.7 LTS (64-Bit) pada VPS dengan service openssh untuk remote server.

2. Setting subdomain yang digunakan beralamatkan pada bbb.aikom.ac.id dimana TLD nya adalah aikom.ac.id yang ditempatkan pada IDWebhost.

3. Valid SSL Certificate yang digunakan adalah Certbot yang di generate sepanjang 4096-bit dengan parameter keamanan Diffie-Hellman.

Selanjutnya penulis melakukan proses update repository pada Ubuntu 16.04.4 LTS.

sudo add-apt-repository ppa:BigBlueButton/support -y

\$ sudo add-apt-repository ppa:rmescandon/yq -y

Setelah proses penambahan repository selesai, selanjutnya adalah menambahkan key dari BigBlueButton dengan perintah:

\$ wget https://ubuntu.BigBlueButton.org/repo/BigBlueButton.asc -o- I sudo apt-key add -

Proses instalasi BigBlueButton dilakukan dengan support HTML5 agar dapat diakses melalui browser.

\$ sudo apt-get install BigBlueButton BigBlueButton-html5 
Jurnal Sistem Informasi dan Sistem Komputer,Vol.6, No.1, Januari 2021

ISSN: 2715-906X (Online)

\section{doi) $10.51717 /$ simkom.v6i1.52}

Setelah berhasil dilakukan instalasi selanjutnya penulis melakukan restart server dan kembali melakukan pengecekan status BigBlueButton untuk memastikan semua berjalan dengan baik.

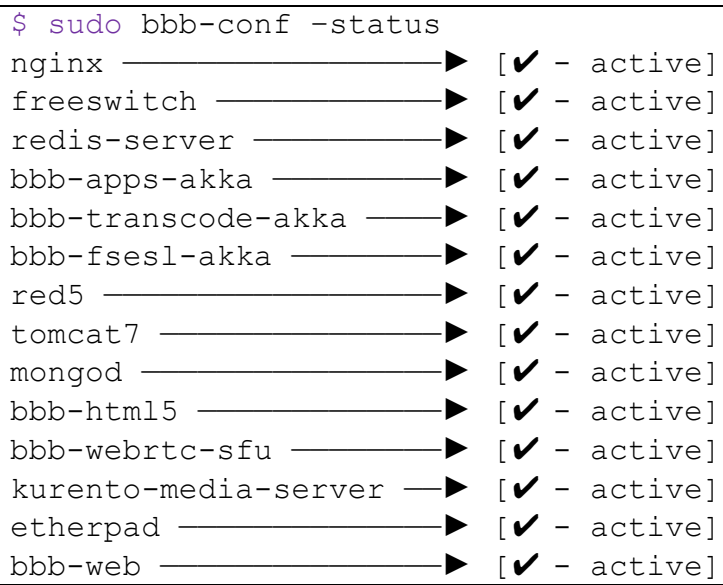

Video meeting dapat diakses pada alamat https://bbb.aikom.ac.id melaui browser desktop, tampilan awal dari video meeting yang diimplementasikan seperti pada Gambar 2 berikut ini:

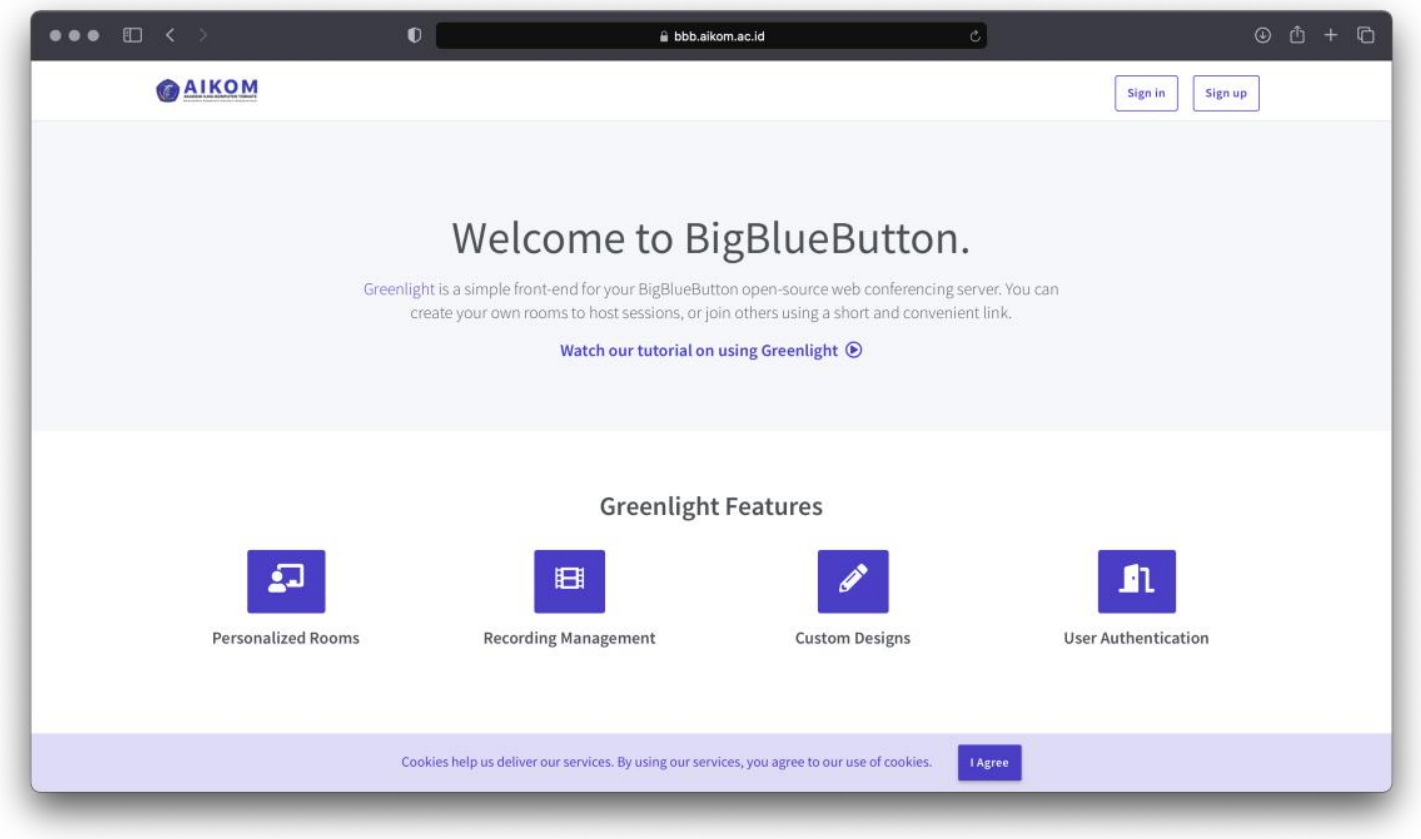

Gambar 2. Tampilan Awal Video Meeting BigBlueButton

Berikut beberapa rule pengguna yang telah terdaftar ditunjukkan pada Gambar 3 berikut ini: 
Jurnal Sistem Informasi dan Sistem Komputer,Vol.6, No.1, Januari 2021

ISSN: 2715-906X (Online)

doi) $10.51717 /$ simkom.v6i1.52

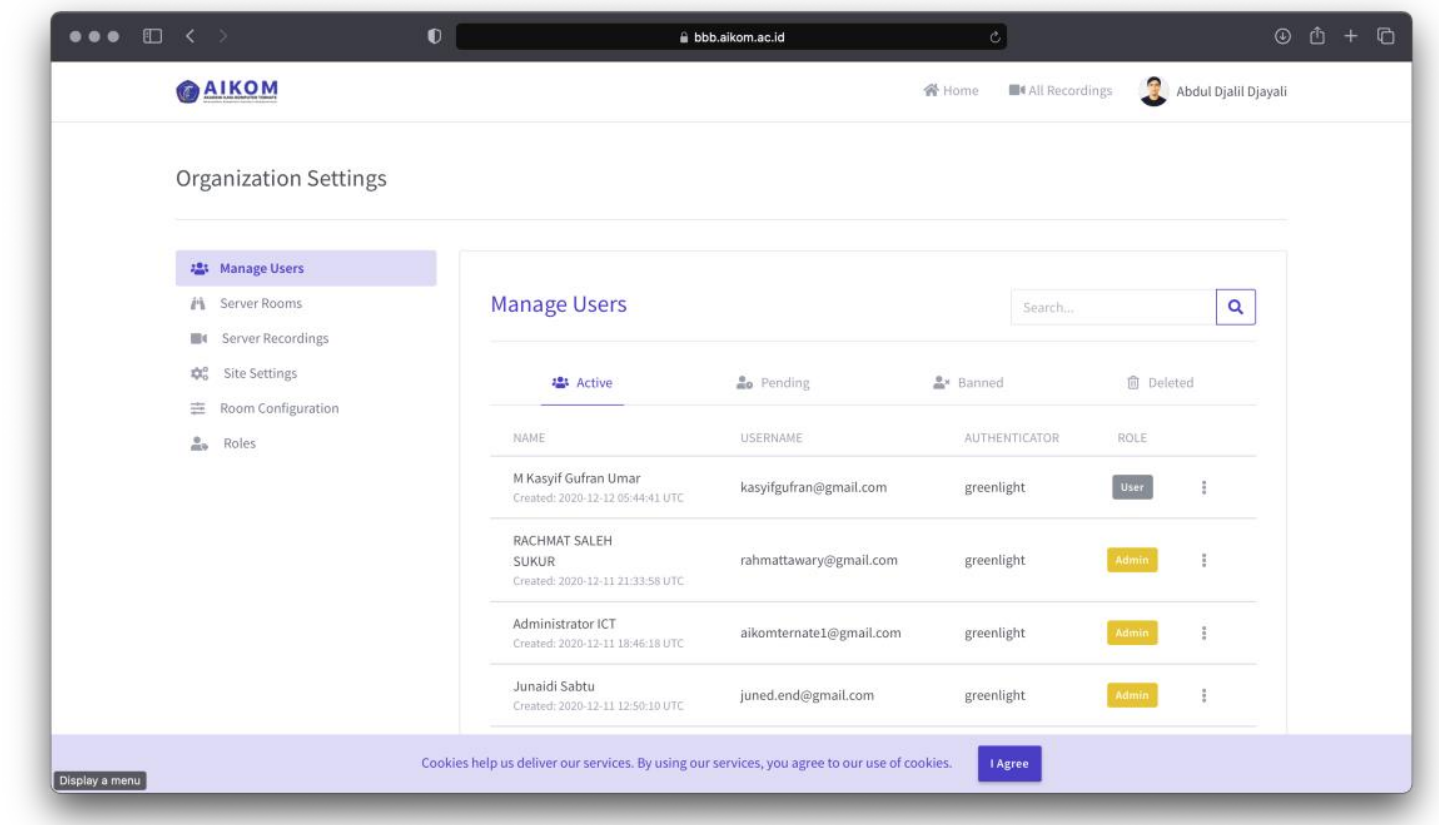

Gambar 3. Tampilan Menage Users pada Video Meeting BigBlueButton

Pengujian dilakukan pada salah satu room yang telah dibuat yakni ICT-AIKOM. Setiap room memiliki kode room yang unique seperti yang terlihat pada Gambar 4.

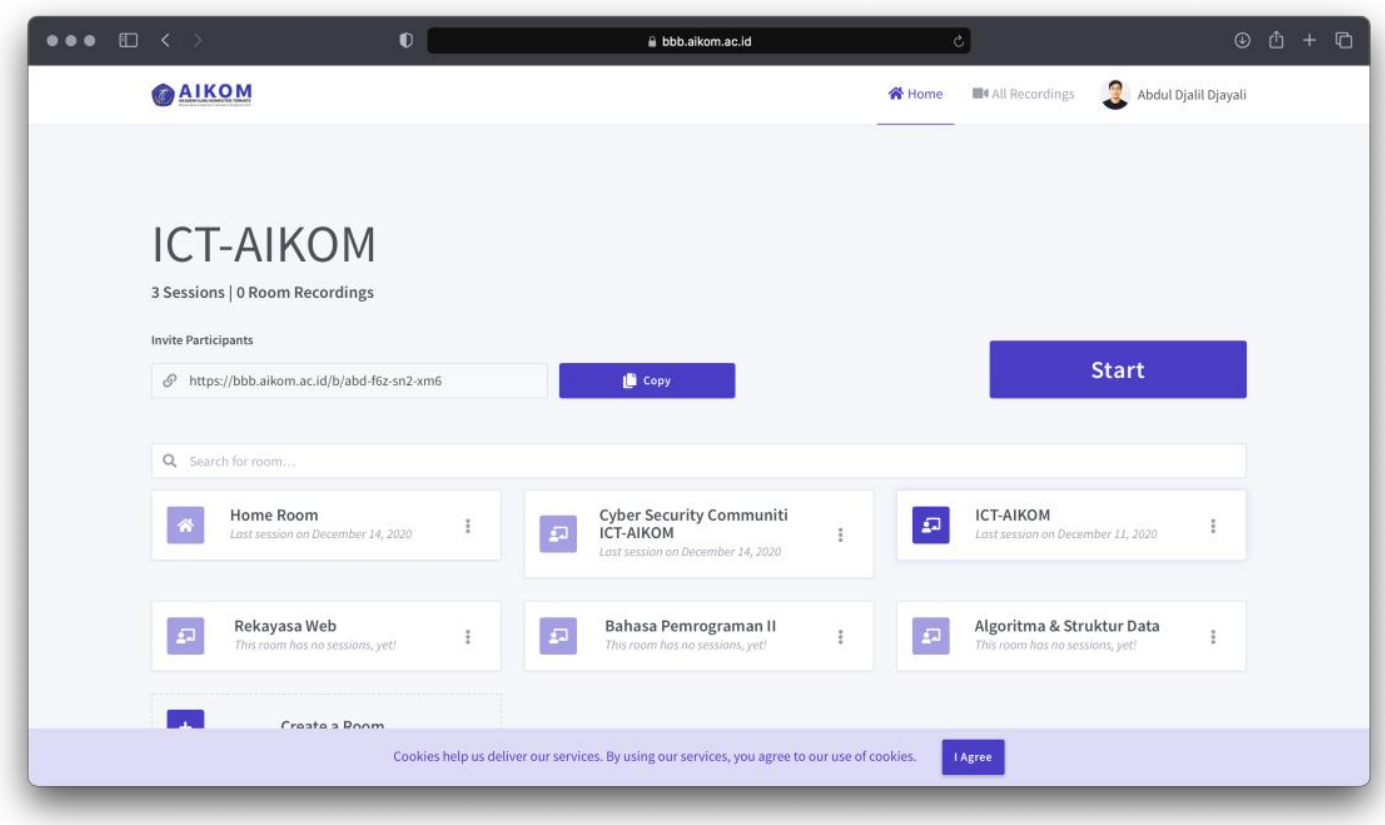

Gambar 4. Tampilan Salah Satu Room Video Meeting BigBlueButton

Tampilan awal ketika memulai meeting, pengguna akan diminta untuk memilih mode audio yang akan digunakan, seperti Microphone untuk mendengarkan dan ikut berbicara atau 
Jurnal Sistem Informasi dan Sistem Komputer,Vol.6, No.1, Januari 2021

ISSN: 2715-906X (Online)

doi) $10.51717 /$ simkom.v6i1.52

Listen Only untuk hanya mendengarkan saja seperti yang ditunjukkan pada Gambar 5 berikut ini:

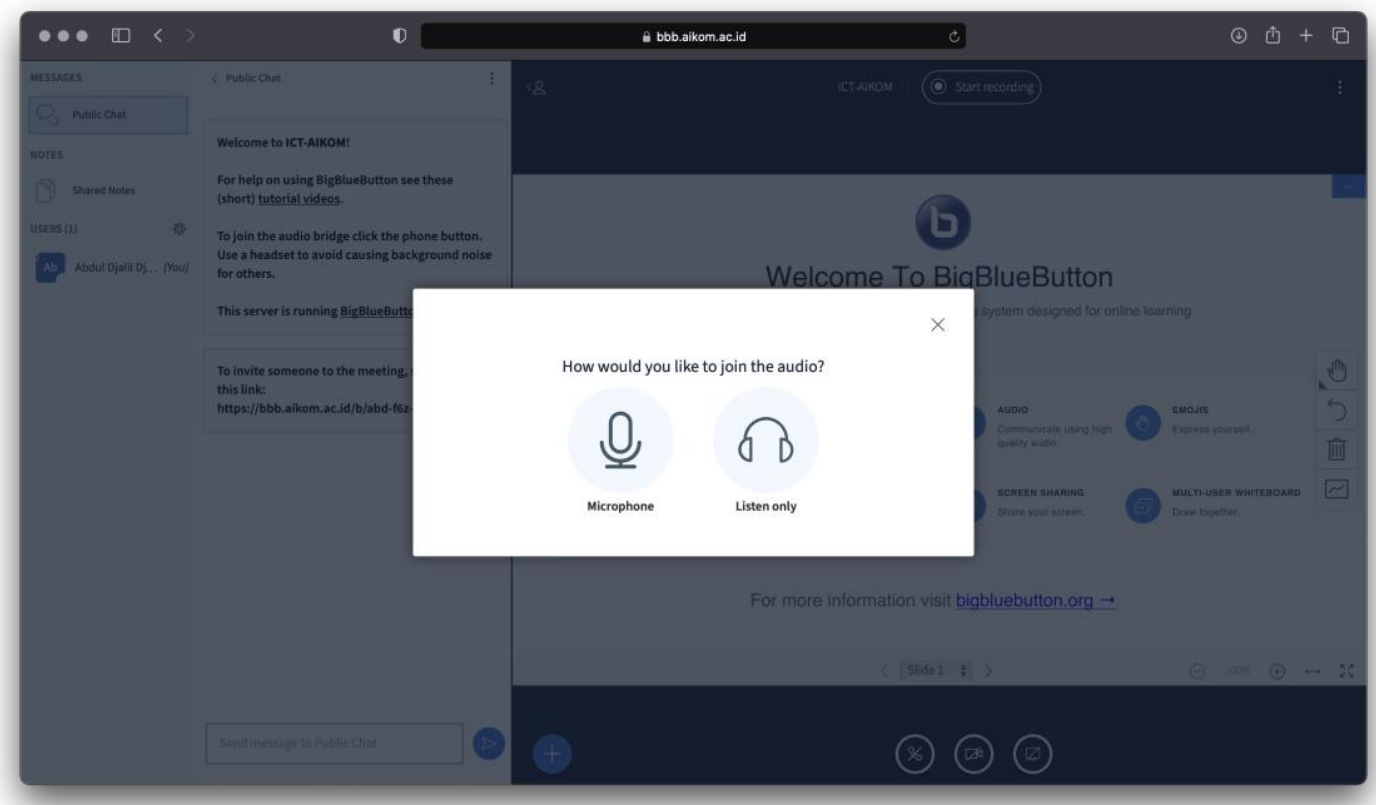

Gambar 5. Tampilan Opsi Join Audio pada Video Meeting BigBlueButton

Tampilan awal dari BigBlueButton yang diterapkan dapat dilihat pada Gambar 6 berikut ini:

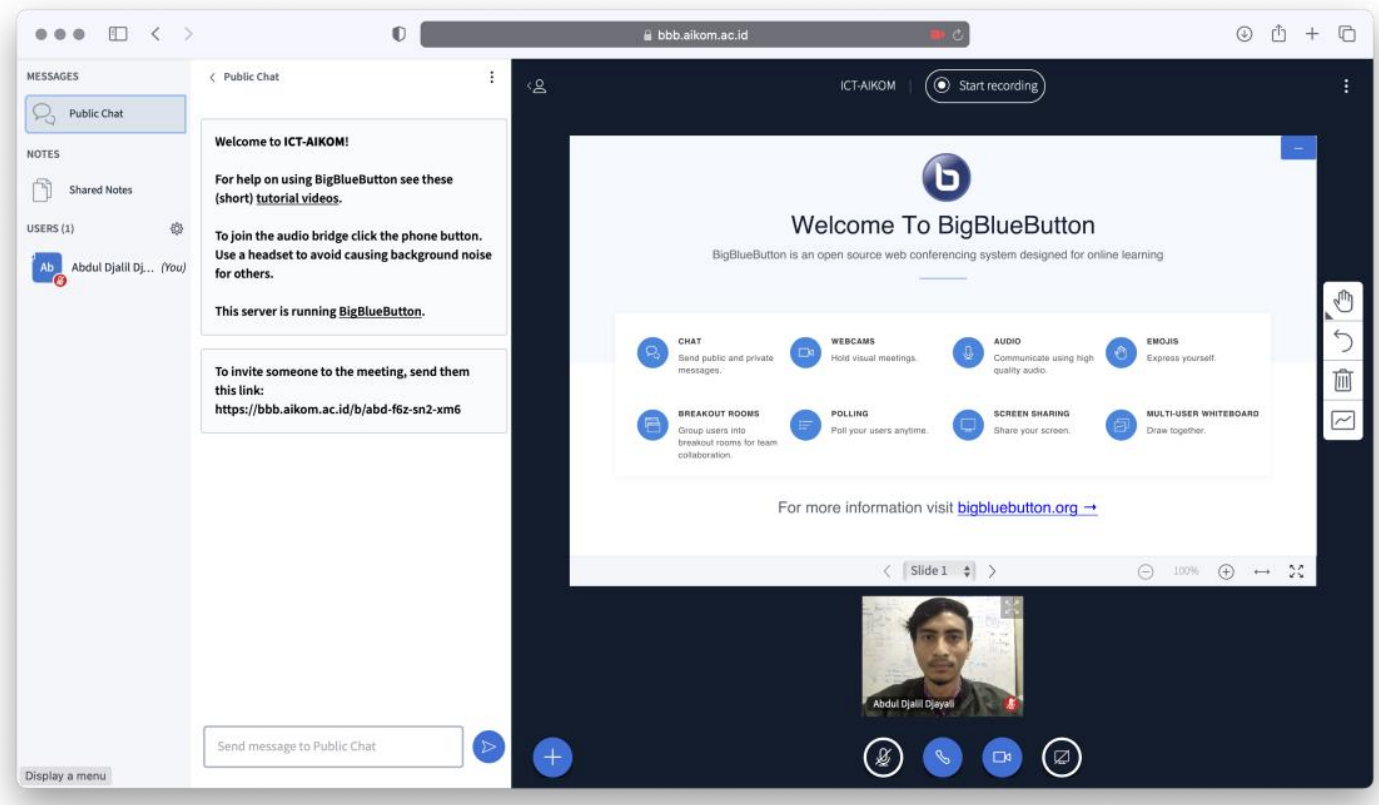

Gambar 6. Tampilan Awal pada Video Meeting BigBlueButton 
Jurnal Sistem Informasi dan Sistem Komputer,Vol.6, No.1, Januari 2021

ISSN: 2715-906X (Online)

\section{doi) $10.51717 /$ simkom.v6i1.52}

Pengujian ini dilakukan oleh 6 pengguna selama 2 jam seperti yang terlihat pada Gambar 7 dibawah ini:

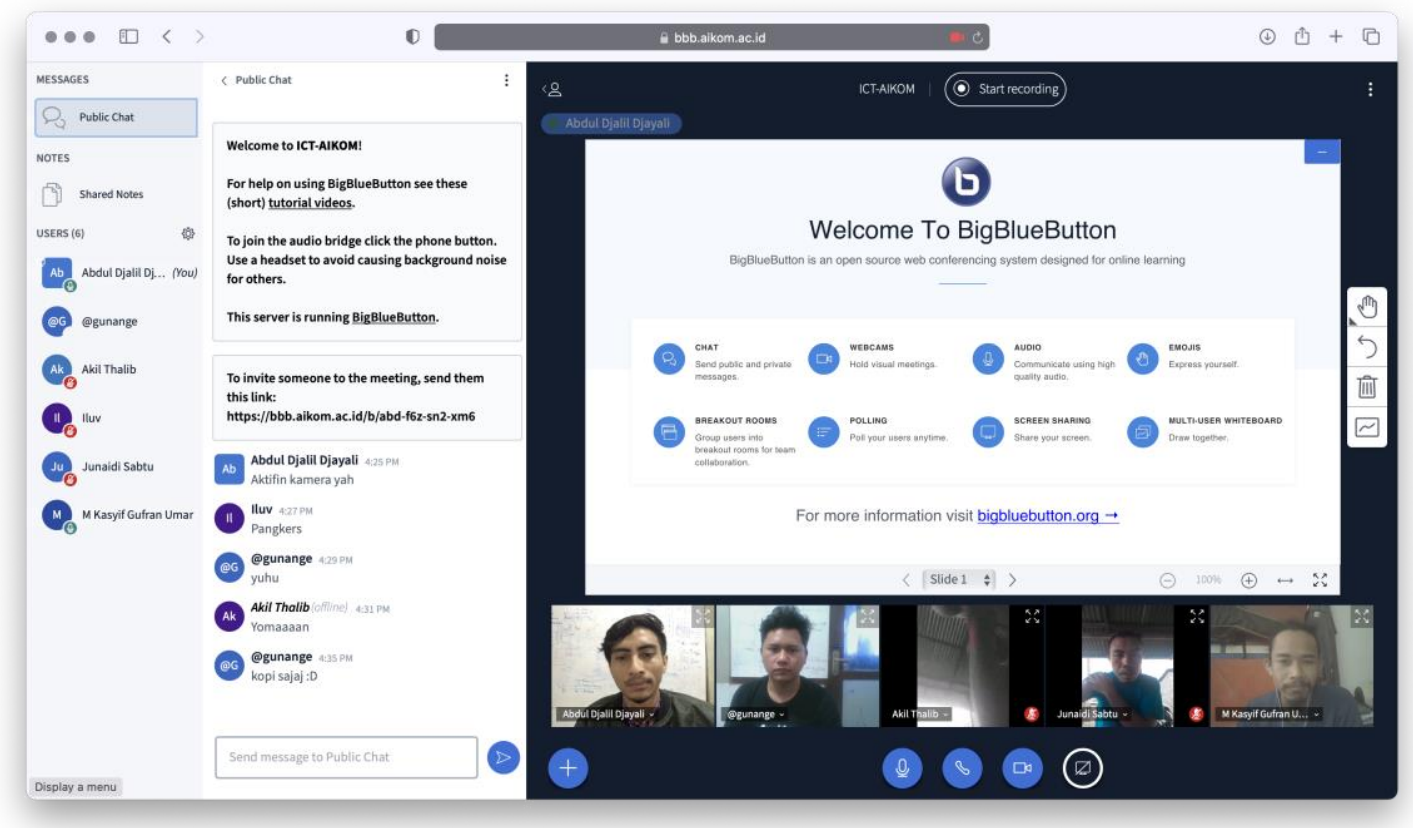

Gambar 7. Tampilan Pengujian Video Meeting BigBlueButton

Terdapat area video conference, fitur chat public, dan daftar peserta conference. Terdapat pula fitur untuk share screen, share presentation, start pooling, dan share video external semisal dari Youtube.

Sedangkan untuk eksplorasi dari sisi mobile, melihat dari tampilan desainnya BigBlueButton dengan teknologi HTML5 ini, merupakan aplikasi video conference yang didesain untuk pengguna mobile. Karena seperti halnya desktop dimana untuk menjalankan aplikasi BigBlueButton ini tidak perlu penambahan aplikasi khusus karena bisa langsung dijalankan menggunakan browser.

Tampilan antarmuka BigBlueButton lumayan user-friendly, karena hampir semua fitur yang dibutukan dari sebuah meeting online dapat dilihat menggunakan BigBlueButton yang diakses melalui perangkat mobile.

Setelah eksplorasi fitur selesai langkah kedua dalam ujicoba ini fokus terhadap kehandalan hardware server dengan menggunakan htop. Hasil dari htop yang terlihat pada Gambar 7 menunjukkan spesifikasi penggunaan sistem. 
Jurnal Sistem Informasi dan Sistem Komputer,Vol.6, No.1, Januari 2021

ISSN: 2715-906X (Online)

doi) $10.51717 /$ simkom.v6i1.52

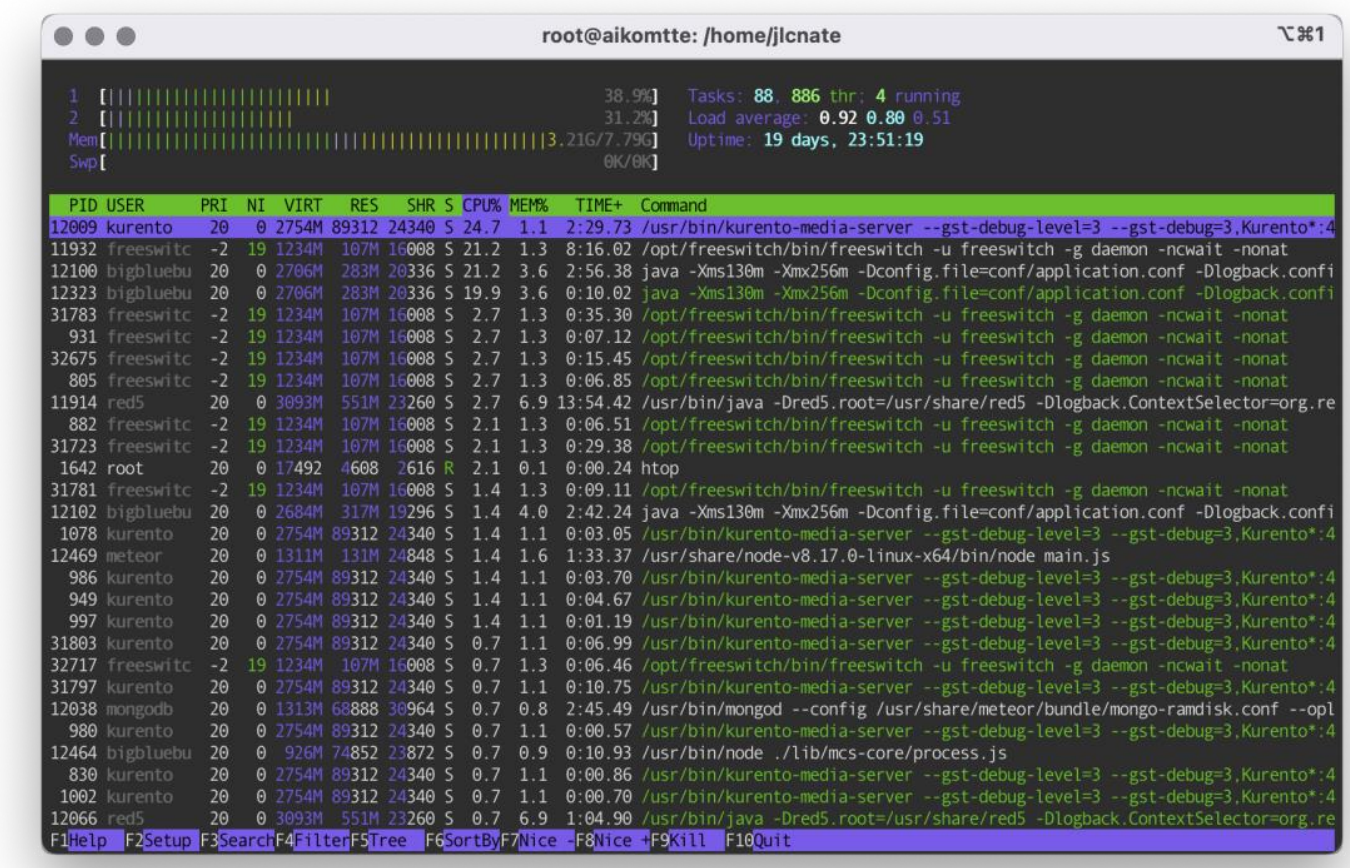

Gambar 7. Tampilan Pengujian htop untuk VPS BigBlueButton

Seperti yang terlihat pada hasil htop diatas, penggunaan video conference BigBlueButton AIKOM Ternate hanya menggunakan RAM sekitar 3.21GB dari total 8GB yang dimiliki, ini artinya belum mencapai setengah dari RAM yang ada.

\section{Kesimpulan dan Saran}

Berdasarkan implementasi yang telah dilakukan menggunakan video meeting open source BigBlueButton yang beralamatkan pada https://bbb.aikom.ac.id ini diperoleh hasil:

1. BigBlueButton memiliki fitur yang sangat memadai dalam menunjang proses pembelajaran di AIKOM Ternate.

2. BigBlueButton mampu untuk melakukan video conference, chat public, dan daftar peserta conference, share screen, share presentation, start pooling, dan share video external seperti dari Youtube.

3. BigBlueButton dapat diakses melalu browser mobile dengan baik.

4. Dalam penggunaannya pada VPS milik AIKOM Ternate, BigBlueButton belum menggunakan setengah dari memori yang ada.

\section{Daftar Pustaka}

[1] H. Sudharta, A. Mulyana, and R. Mayasari, "Implementasi dan analisis aplikasi e-learning untuk layanan video conference dalam kegiatan kuliah jarak jauh,” 2012.

[2] Menteri Agama, "Surat Edaran Nomor 5 tahun 2020 tentang Penyesuaian Sistem Kerja Pegawai dalam Upaya Pencegahan Corona Virus Desease (Covid-19) Pada Lingkungan Kementerian Agama. Kementerian Agama." 2020.

[3] M. McLaughlin, "The Best Video Conferencing Software for 2020," pcmag.com, 2020. 
Jurnal Sistem Informasi dan Sistem Komputer,Vol.6, No.1, Januari 2021

ISSN: 2715-906X (Online)

doi $10.51717 /$ simkom.v6i1.52

https://sea.pcmag.com/videoconferencing/4839/the-best-video-conferencing-software-for-2020 (accessed Dec. 30, 2020).

[4] D. (Universitas B. S. I. Laksmiati, "IMPLEMENTASI CLOUD BASED VIDEO CONFERENCE SYSTEM MENGGUNAKAN JITSI,” J. Chem. Inf. Model., vol. 53, no. 9, pp. 1689-1699, 2019.

[5] A. B. Kusuma, A. Yusuf, and A. Hidayat, "Implementasi Dan Analisis Server Bigbluebutton Dalam Pemanfaatan Meeting Online Pada Masa Pandemic," Walisongo J. Inf. Technol., vol. 2, no. 1, p. 27, 2020, doi: 10.21580/wjit.2020.2.1.5572.

[6] R. Eka, A. Rachman, and T. Wahyu, "Virtual Private Server ( VPS ) Sebagai Alternatif Pengganti Dedicated Server," Semin. Intell. Technol. Its Appl. SITIA, pp. 2-7, 2010.

[7] BigBlueButton, "BigBlueButton: Open Source Web Conferencing," BigBlueButton. . 